\title{
Influence of Guidance and Counselling Programmes on Secondary Students School Connectedness. A Case Study of Nyamira County, Kenya
}

\author{
James Kay: Kabarak University, Kenya. \\ James Muola: Machakos University, Kenya. \\ -Paul C. Ondima: Kisii University, Kenya.
}

\begin{abstract}
Secondary school students are still within the age bracket of rapid physical, social and psychological changes. These changes pose a number of challenges which result to cases of maladaptive behaviour as evidenced by strikes, riots, boycotts, indulgence in premarital sexual activities, truancy, drug and substance abuse, disinterest in school and poor academic performance. Diverse behaviour modification strategies have been employed to mitigate against these negative tendencies but these maladaptive behaviours are still rampant among secondary school students. The current study sought to investigate the influence of guidance and counselling programmes in improving secondary students school connectedness in Nyamira Count,y Kenya. The study objective was to investigate the influence of guidance and counselling programmes on secondary students school connectedness. The study was guided by two theories namely: Ludwig Bertalanffy's Systems Theory and Erik Erickson's psychosocial development Theory. The study utilized descriptive survey design as well as ex-post facto design. The sample size of the study were 52 head teachers, 52 deputy head teachers, 52 guidance and counselling teachers and 311 students drawn from a population of 7740 form three students, 174 head teachers, 174 deputy head teachers and 174 guidance and counselling teachers. Purposive sampling procedure was used to select public secondary schools, head teachers, deputy head teachers, guidance and counselling teachers and form three students. Stratified sampling procedure was used to group the target population into four strata based on school type and gender. Proportionate sampling procedure was used to select equal representation of respondents from each stratum of public secondary school. Random sampling procedure was used to obtain the final sample from each of the stratum. Questionnaires and interview schedules were used to collect data. Prior to data collection, a pilot study was conducted to ensure validity and reliability of the research instruments and using Cronbach reliability test, reliability coefficient of $\alpha=0.727$ was reported. Descriptive and inferential statistics was used to analyze the data. The data analysis was done with the aid of computer software-statistical package for social sciences (SPSS) version 22.0. The study found that there is a strong positive relationship $(r=.622)$ between guidance and counselling programme and students school connectedness which was statistically significant $(\rho<.005)$. The study recommends that all teachers in the school need to understand in depth the concept of guidance and counselling in the school setting and how it can be used to improve students school connectedness. The education ministry should organize regular seminars based on personal, social and moral practices for the schools. This will ensure that the policy on professional ethics is adhered to for improved performance. The government through the Ministry of Education and Teachers Service Commission should employ more teacher counselors in secondary schools to effectively tackle social and academic challenges facing the students.
\end{abstract}

Vol. 2, No.3, pp. 151-162

2019

DOI: $10.53935 / 2641-533 x . v 2 i 3.117$

Corresponing Author: Paul C. Ondima

Received: 27 June 2019

Revised: 21 August 2019

Accepted: 2 October 2019

(C) 2019 by the authors; licensee Academic

Publishing Group
Key words: Guidance, Counselling, Public secondary schools, Students school connectedness, Nyamira County. 


\section{Introduction}

Guidance and counselling, possibly in different forms and with different interpretations has existed in societies for centuries and across civilization. The terms "Guidance and counselling" have been conceived differently by different scholars. According to Gauta (2012) guidance and counselling is a process through which some people assist others come to grips with distressing problems of everyday living. Okolie and Nweze (2014) define guidance and counselling as a helping career which is a moulding, rebuilding and rehabilitating process. It is a self- directing relationship which is both preemptive and restorative of maladaptive tendencies. According to Lunenburg (2010). From time immemorial, individuals have been faced with problems and there are periods of time in life when self- efforts at personal, emotional, social, educational and vocational problemsolving and mental health activities fail. There is also time in life when the help of even non-professionals such as friends fail to resolve an individual's psychological problems. In such periods professional guidance and counselling services become inevitable. Thus the need for guidance and counselling programmes in secondary schools and other learning institutions can not be overemphasized owing to increasing complexities of modern life that have placed heavy demands and responsibilities on secondary school students. These students are faced with numerous personal, academic and emotional challenges which if not attended to could lead to maladaptive behaviour tendencies. Secondary school students who are within the age bracket of adolescence undergo significant developmental changes in the context of changing relationships with parents and peers, often in combination with the transition to a new school (Shochet \& Smith, 2011). Achieving positive psychological adjustment through this intense developmental period depends in part on the interaction between each individual and his or her environment.

The school setting is a central social context whose impact on adolescent development is being increasingly recognized by researchers (Carey, Harrington, Martin, \& Hoffman, 2012; Whiston, Tai, Rahardja, \& Eder, 2011). Youths in high schools worldwide spend up to a quarter of their lives in schools and this makes the school a potentially powerful context for influencing young people and the relations formed in the school with the adults, teachers and the peer group have a great influence on the lives of the youths (Machingambi, 2012).

Thus schools should do what they can to establish suitable environments that are healthy, safe, supportive, clean and pleasant and one of the effective strategies of creating such an environment is the development of a robust guidance and counselling programme, which in turn enhance students school connectedness.

The concept of students school connectedness is one that has received a great deal of attention in developed countries particularly in the United States. School connectedness has been defined as the belief by students that adults and peers in the school care about their learning as well as about them as individuals. Thus it indicates the extent to which students feel cared for within the school context. It focuses on individual's perceptions of themselves within interpersonal relationships in the school setting. Over the years educational and health researchers have recognized that social and psychological connectedness to school is a protective and promotive factor for all youths. Students feel connected to the school environment when there is strong teacher support and an atmosphere in which adults and student relationships are positive and respectful within a physically and emotionally safe context (Machingambi, 2012).

Connected students have been found to be less likely to use state altering substances; to exhibit emotional distress, demonstrate deviant behaviour, experience suicidal ideation or to undergo early sexual initiation. Besides, connected students have been found to demonstrate a higher sense of belonging, self-esteem and positive socio- emotional well-being. Mohan (2010) in a study in Vancouver found out that the more connected youth feel to school, the more likely they are to report good health or excellent health as well as higher self-esteem, and the less likely they are to have considered suicide. The study too established that school connectedness can have positive effect reaching into young adulthood, resulting in lower rates of substance use, better mental health and higher school completion rates (Ross, Shochet, \& Bellair, 2010). A study carried out in the United States of America established that when young people receive empathy attention and praise at school, they feel a sense of belonging and support that leads to healthy growth and development (Shochet \& Smith, 2011).

A study by established that in Zimbabwe and other developing countries the problem of student disconnectedness is more real than in developed countries. This is because students in such countries operate 


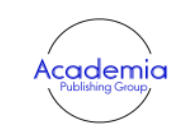

International Journal of Educational

Studies

Vol. 2, No.3, pp. 151-162

2019

DOI: $10.53935 / 2641-533 x . v 2 i 3.117$

"Corresponding Author: Paul C. Ondima

Funding: This study received no specific

financial support.

Article History:

Received: 27 June 2019

Revised: 21 August 2019

Accepted: 2 October 2019

Published: 8 November 2019

(C) 2019 by the authors; licensee Academic

Publishing Group in overcrowded classrooms, overworked teachers and poor infrastructures, autocratic leadership styles in school and class and curricular that are not always perceived as relevant amid examinations that are often way beyond the ability of a large number of students. This creates the feeling that the school environments are not as sensitive to their needs as they should be. The study found out that the big challenge for schools is therefore to create and sustain in schools a feeling of belonging to schools, a belief that teachers and other adults as well as peers care about them and their learning, belief that education matters and that it is important to have and to hold friends in schools and that discipline procedures in their schools are fair and in their own best interests. posit that effective guidance and counselling programmes can help create a healthy school environment that will enhance student connectedness.

According to Onderi and Makori (2013) cases of maladaptive behaviour among secondary school students in Nyamira County have been on an upward trend over the years and this is one of the serious problems Principals in secondary schools in Nyamira County are facing. In their opinion, this state of affairs is due to poor relationship between teachers and adults in the schools and hostile school environments for students. They propose the need for school administrators to come up with strategies of managing students' behaviour which create a conducive learning atmosphere in schools characterized by improved teacher student relationship; active student participation in school activities and empowerment of students to take responsibility for their behaviour in a socially accepted manner. In their opinion, strengthening of guidance and counseling programme in secondary schools in Nyamira County may contribute to creating a warm school environment for students which will in turn enhance students connectedness to the schools. It is against this background that this study was designed to assess the extent to which guidance and counselling programme improved secondary students connectedness to the schools in Nyamira County, Kenya.

\subsection{Statement of the Problem}

Many secondary school students in Kenya are characterized by strikes, riots, high drop out rates, drug and substance abuse and pre marital sexual activities which are indicative of maladaptive behaviour among secondary school students. Secondary schools in Nyamira County are not an exception with regard to these maladaptive tendencies. Stakeholders have advanced a number of contributory factors to this state of affairs among which are; poverty, inappropriate role models, weak students school connectedness, low self esteem, unfriendly school environments, weak academic engagement and general systemic weaknesses in the education system. In a bid to address these challenges, the Ministry of Education has established a guidance and counselling department in every secondary school including those in Nyamira County. Inspite of this, the aforementioned cases of maladaptive behaviours are still rampant in many secondary schools in Kenya in general and those in Nyamira County in particular. Unless these maladaptive behaviour are tackled, the education system will continue churning out youths with low self esteem and who lack the necessary life skills to make them responsible individuals who will contribute to the development of society. It is therefore pertinent to ask the question, how do the secondary schools in Nyamira County use guidance and counselling programme to enhance students adaptive behaviour, in general and students connectedness in particular.Considering this question, the problem of this study was to examine the influence of guidance and counselling in improving secondary students school connectedness in Nyamira County.

\subsection{Purpose of the Study}

The purpose of this study was to establish the influence of guidance and counselling programmes in improving secondary students' school connectedness in Nyamira County. The aim was to evaluate the extent to which guidance and counselling programmes are used to enhance students school connectedness.

\subsection{Research Hypothesis}

To investigate the influence of guidance and counselling programmes on secondary students school connectedness in Nyamira County, the study tested the following null hypothesis:

H0: There is no statistically significant relationship between guidance and counselling programmes and secondary students school connectedness. 


\subsection{Significance of the Study}

The study is significant as it will provide valuable information regarding the influence of guidance and counselling programmes in promoting students connectedness to the schools. Findings from the study will shed light on how guidance and counselling can be used to enhance students connectedness to the schools and hence an improvement in the learning environment in the schools. The Ministry of education may utilize the results of the study to come up with policies on how to strengthen guidance and counselling programmes in secondary schools through provision of adequate physical and human resources for them to play a more vital role in promoting adaptive behaviour in general and secondary students school connectedness in particular.

The study may help to sensitize secondary school administration on the role that guidance and counselling programmes can play in creating appropriate school environments that can boost students school connectedness. Students may also benefit from the study as it will help them realize the relationship between guidance and counselling and their connectedness to the schools and the need for them to fully utilize the programmes to their advantage. The study is also significant as it will act as an eye opener to researchers to develop more interest in searching for further knowledge on different aspects of guidance and conselling such as new approaches and techniques of guidance and counselling in a bid to make it more effective in handling different aspects of students behaviour. This will add to the pool of knowledge which is vital to the present and future generations.

\section{Methodology}

The study utilized descriptive survey design with both qualitative and quantitative approaches. This design is defined by Frankel and Wallen (2014) as asking a large group of people questions about a particular issue. Using this design the researcher collected both qualitative and quantitative data at the same time and then integrated the information in the interpretation of the overall results. This design is more appropriate because it increases the overall strength of a study by enhancing the validity and trustworthiness of the data. Purposive sampling procedure was used to select public secondary schools, head teachers, Deputy Head teachers, guidance and counselling teachers and form three students. Stratified sampling procedure was used to group the target population into four strata based on school type and gender. Proportionate sampling procedure was used to select equal representation of respondents from each stratum of public secondary school. In all the sample size of the study were 52 head teachers, 52 deputy head teachers, 52 guidance and counselling teachers, 311 students drawn from a population of 174 head teachers, 174 Deputy head teachers, 174 guidance and counselling teachers and 7740 form three students.

\subsection{Instrumentation}

Open and closed ended structured self report questionnaires and interview schedules were used in this study to elicit the required data from the respondents. Three different questionnaires were used. The first was the Head teacher/Deputy head teacher questionnaire HD/HTQ). The second was the guidance and counselling teacher questionnaire (GCTQ). The third questionnaire sought to obtain data from students (SQ). All the three questionnaires sought to obtain data from the respondents on maladaptive behaviours, the guidance and counselling services provided and the effect of such services on students school connectedness. For the purpose of this study, the researcher also utilized the interview schedules: one for obtaining data from Deputy head teachers (DHTIS) and another for eliciting data from guidance and counselling teachers (GCTIS). The interview schedules gathered information on guidance and counselling programmes and their impact on student school connectedness.

\begin{tabular}{l} 
International Journal of Educational \\
Studies \\
Vol. 2, No.3, pp. 151-162 \\
2019 \\
DOI: $10.53935 / 2641-533 x . v 2 i 3.117$ \\
Corresponding Author: Paul C. Ondima \\
Funding: This study received no specific \\
financial support. \\
Article History: \\
Received: 27 June 2019 \\
Revised: 21 August 2019 \\
Accepted: 2 October 2019 \\
Published: 8 November 2019 \\
○) 2019 by the authors; licensee Academic \\
Publishing Group \\
\hline | 154
\end{tabular}

\subsubsection{Validity and Reliability of the Instrument}

Both content and face validity of the instruments was established Cronbach alpha test of reliability for likert scale was used to address the question of consistency of the tool. An alpha $(\propto)$ value equal or greater than 0.7 was considered an acceptable value for the tool to be viewed as reliable. Questionnaires for school Principals had a reliability coefficient of $\propto=0.742$, questionnaire for teacher counsellor $\propto=0.630$, questionnaire for students $\propto=0.809$. The overall reliability for the 30 items in the questionnaires was $\propto=0727$. Considering the threshold of 0.7 for social sciences the questionnaire was thus found to be reliable as $\propto=$ $0.727>0.7$. Content validity was assured through collation of the structure of questionnaires and interview schedules with the research objectives and literature review. During the pilot study an analysis of the 
respondents' reasons for their responses was carried out to establish the comprehensibility, that is clarity of each item and clarity of instructions, relevance of the items and absence of biased words and phrases. Piloting therefore assisted in making necessary amendments to enhance validity of the instruments.

\subsubsection{Administration of Instruments}

The permit for the study was obtained from the National Commission for Science, Technology and Innovation (NACOSTI). The County Education Officer, Nyamira was then contacted to allow the researcher proceed to the secondary schools in the County to collect data. With the permit, an introductory letter from Kabarak University and consent from the County Education Officer, the researcher visited the sampled schools for data collection. The consent of the head teachers of the respective schools was sought and they were consulted on the day and time for the researchers to administer the instruments. During the administration of the research instruments clear instructions were given on the purpose of data collection and the ethical considerations. Only those who volunteered were included in the study. The instruments were collected the same day, as soon as the respondents completed filling them. Data that was obtained from head/deputy head teachers and guidance and counselling teachers through interview was recorded by the researchers during the interview.

\subsubsection{Data Analysis}

Data that was generated by this study was mainly quantitative. Descriptive and inferential statistics were therefore used in the data analysis. Quantitative data was analyzed using descriptive statistics like frequencies and percentages. To investigate the relationship between the variables, both regression and correlation analysis was used. Linear regression analysis was used to assess the association between the variables and the findings summarized in models and coefficient tables. For correlation analysis, Pearson correlation test was used to test the strength of association or correlation between the variables, that is how guidance and couneslling programmes in secondary schools correlate with students school connectedness. Qualitative data obtained from the interview with the head teachers/deputy head teachers and teacher counselors was analyzed thematically by arranging responses according to the research objectives. The results of data analysis was presented using frequency distribution tables, pie charts and bar graphs. The data analysis was done with the aid of computer software-statistical package for social sciences (SPSS) version 22.0. In order to make reliable inferences from the data, the statistical tests were subjected to tests of significance level of 0.05 .

\subsubsection{Ethical Considerations}

The study followed a set of standards of ethics to ensure integrity and competence. First, the researchers ensured that the study is free of plagiarism. This was done by acknowledging all the consulted sources and citing each of them appropriately following the APA referencing style. Second, the researchers endeavored to obtain consent from respondents by informing them of the significance of the study and the need for them to participate in the study. The respondents willing to participate in the study were then asked to sign consent forms. Third, the researchers ensured that the privacy of the respondent's remain anonymous and confidential. This was done by asking them not to reveal their identity on the data collection instruments. Besides, the respondents were assured that the information they volunteered would be handled carefully and with confidentiality and that it would be used only for the intended academic purpose. In addition, permission was sought from all the relevant authorities prior to data collection.

\section{Findings of the Study}

The study objective sought to establish the effect of guidance and counselling programme on students school connectedness. Thus data was collected to measure secondary students school connectedness and further analysis conducted using correlation and regression to determine the relationship between guidance and counselling programmes and students school connectedness. Results were as presented in subsequent figures and tables.

\subsection{Main Guidance and Counselling Services in Schools and Mode of Delivery}

Teacher counsellors were probed on the main guidance and counselling services provided in the schools and mode of delivery. They were therefore first asked to indicate whether they had guidance and counselling

Published: 8 November 2019
() 2019 by the authors; licensee Academic
Publishing Group
| $\mathbf{1 5 5}$


departments in their schools, main guidance and counselling services provided and mode of counselling used in the provision of guidance and counselling services. The findings are shown in Figure 1.

\section{Main G\&C services provided in school and mode of Counseling used}

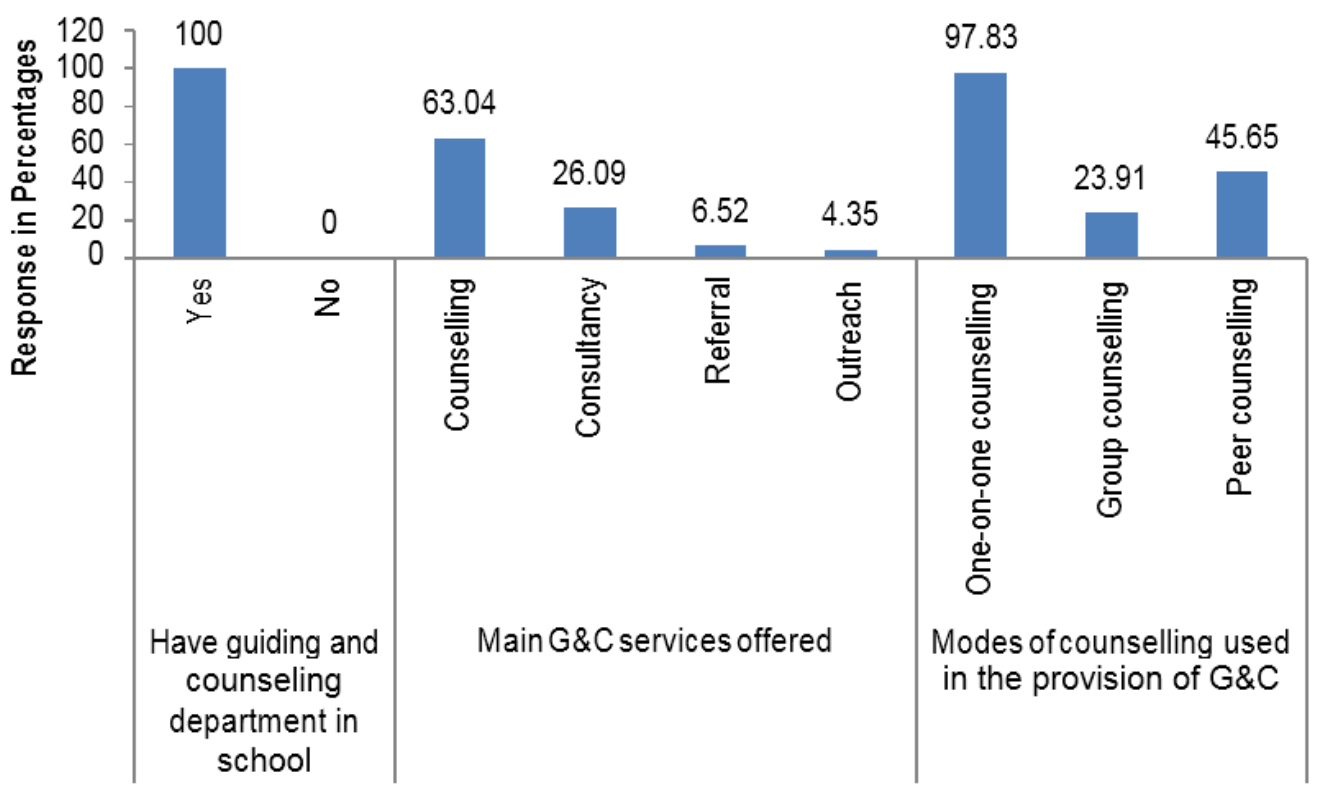

Figure-1. Main Guidance and counselling services in schools and mode of delivery.

Figure 1 shows the findings. According to the teacher counsellors who took part in the study, all at $100 \%$ agreed that they had guidance and counselling department in their schools. When probed on main services offered by the department, over 26,09\% mentioned referral and outreach respectively. On modes of counselling used in the provision of guidance and counselling services, almost all the respondents at $97.83 \%$ indicated one-on-one counselling, $23.91 \%$ indicated group counselling while $45.63 \%$ mentioned peer counselling. This shows that the main modes of administration of guidance and counselling services were one-on-one and peercounselling.

\subsection{Frequency of Meetings between Teacher Counsellors and Students}

Respondents were asked to indicate how often teacher counsellors meet students for guidance and counselling sessions. The results are shown in Figure 2.

As Figure 2 above indicates, the study found that in most cases guidance and counselling sessions were mainly carried out whenever problems arose among the students as shown by $75.23 \%$ of the respondents. However, more than two thirds of the respondents at $1.32 \%$ indicated that guidance and counselling sessions were carried out less than 3 times a week. Only $11.72 \%$ indicated more than 5 times a week, which $23.91 \%$ indicated 3-5 times a week. The study also established that the time assigned for guidance and counselling the students given the number of clients the counsellor had to copy with was not adequate as shown by $59.41 \%$ of the respondents. Only $40.59 \%$ indicated otherwise.

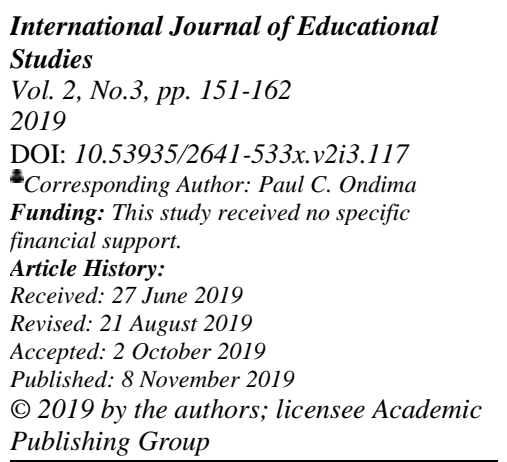




\section{Students Response to G\&C services and Rating its success to academic performance}

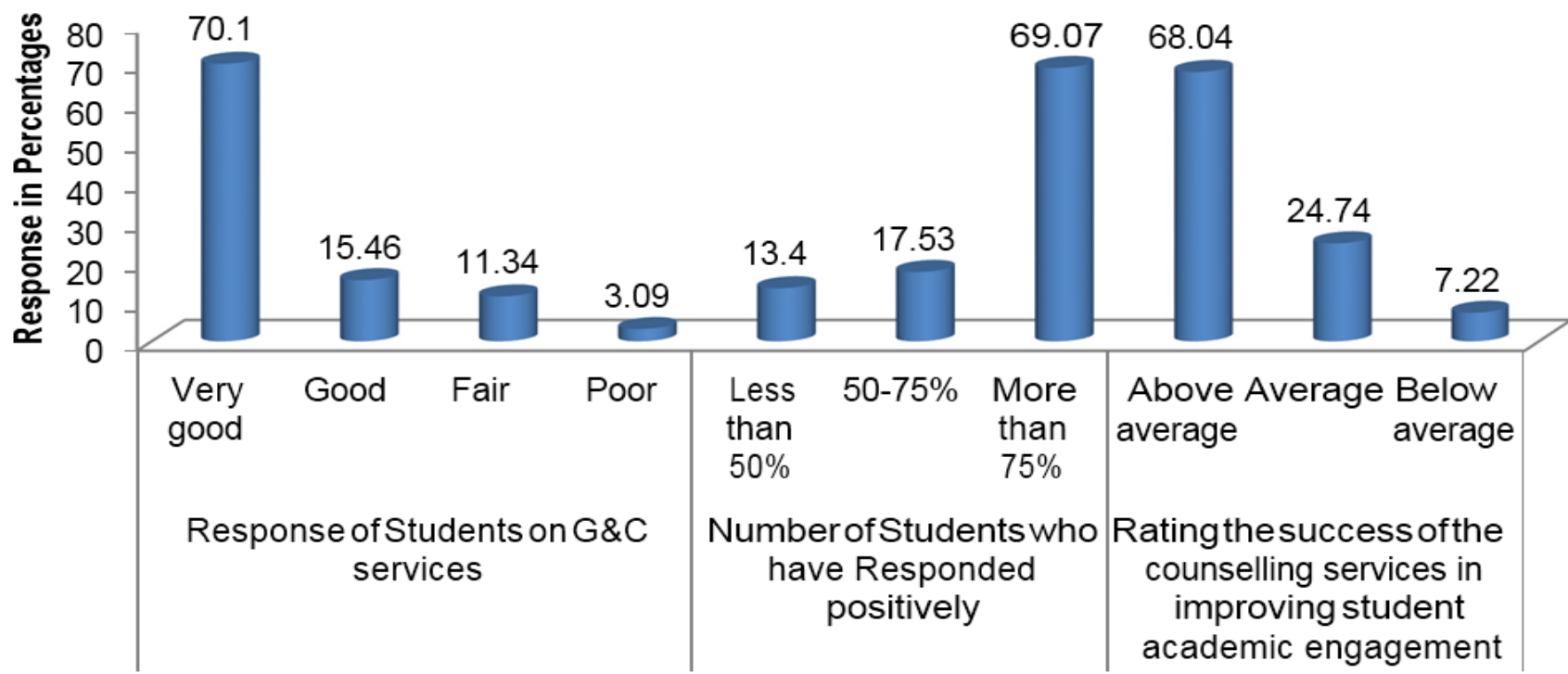

Figure-2. Frequency of meetings between teacher counsellors and students.

3.3. Secondary School Principals/Deputy Principals' Views on Effect of Guidance and Counselling Programme on Students School Connectedness

Secondary school Principals/Deputy Principals were asked to indicate how guidance and counselling programmes improved students connectedness. The statements were measured using a 5-item 5-point likert scale as $1=$ strongly disagree, $(\mathrm{SD}), 2=$ Disagree $(\mathrm{D}), 3=$ Neutral $(\mathrm{N}), 4=$ Agree $(A)$, and $5=$ Strongly agree (SA). The data obtained to show frequency of each response as well as percentage per item is shown in Table 1.

Table-1. Secondary school Principals/Deputy Principal's views on effect of guidance and counselling programme on students school connectedness.

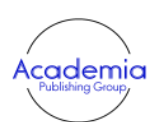

International Journal of Educational Studies

Vol. 2, No.3, pp. 151-162

DOI: $10.53935 / 2641-533 x . v 2 i 3.117$

Corresponding Author: Paul C. Ondima

Funding: This study received no specific

financial support.

Article History:

Received: 27 June 2019

Revised: 21 August 2019

Accepted: 2 October 2019

Published: 8 November 2019

(C) 2019 by the authors; licensee Academic

Publishing Group

\begin{tabular}{|c|c|c|c|c|c|}
\hline Statement & SA & $\mathbf{A}$ & $\mathbf{N}$ & $\mathbf{D}$ & SD \\
\hline Improves students sense of belonging to the school & $\begin{array}{l}88 \\
(90.72 \%)\end{array}$ & $\begin{array}{l}4 \\
(4.12 \%)\end{array}$ & $\begin{array}{l}4 \\
(4.12 \%)\end{array}$ & $\begin{array}{l}0 \\
(0.00 \%\end{array}$ & 1 \\
\hline Enhances student teacher consultation & $\begin{array}{l}85 \\
(87.63 \%)\end{array}$ & $\begin{array}{l}3 \\
(3.09 \%)\end{array}$ & $\begin{array}{l}8 \\
(8.25 \%)\end{array}$ & $\begin{array}{l}1 \\
(1.03 \%\end{array}$ & $\begin{array}{l}0 \\
(0.00 \%)\end{array}$ \\
\hline Boosts teachers respect towards students opinions & $\begin{array}{l}87 \\
(89.69 \%)\end{array}$ & $\begin{array}{l}3 \\
(3.09 \%)\end{array}$ & $\begin{array}{l}5 \\
(5.15 \%)\end{array}$ & $\begin{array}{l}2 \\
(2.06 \%)\end{array}$ & $\begin{array}{l}0 \\
(0.00 \%)\end{array}$ \\
\hline Enhances students pride towards their school & $\begin{array}{l}85 \\
(87.63 \%)\end{array}$ & $\begin{array}{l}8 \\
(8.25 \%)\end{array}$ & $2.06 \%$ & $\begin{array}{l}0 \\
(0.00 \%)\end{array}$ & $\begin{array}{l}2 \\
(2.06 \%)\end{array}$ \\
\hline Improves teacher-student relationship & $\begin{array}{l}84 \\
(86.60 \%)\end{array}$ & $\begin{array}{l}5 \\
(5.15 \%)\end{array}$ & $\begin{array}{l}4 \\
(4.12 \%)\end{array}$ & $\begin{array}{l}2 \\
(2.06 \%)\end{array}$ & $\begin{array}{l}2 \\
(2.06 \%)\end{array}$ \\
\hline $\begin{array}{l}\text { Promotes teachers and other adults concern towards } \\
\text { students welfare }\end{array}$ & $\begin{array}{l}87 \\
(89.69 \%)\end{array}$ & $\begin{array}{l}4 \\
(4.12 \%)\end{array}$ & $\begin{array}{l}2 \\
(2.06 \%)\end{array}$ & $\begin{array}{l}3 \\
(3.09 \%)\end{array}$ & $\begin{array}{l}1 \\
(1.03 \%)\end{array}$ \\
\hline $\begin{array}{l}\text { Enhances students participation in extra-curricular } \\
\text { activities in school }\end{array}$ & $\begin{array}{l}77 \\
(79.38 \%)\end{array}$ & $\begin{array}{l}11 \\
(11.34 \%)\end{array}$ & $\begin{array}{l}4 \\
(4.12 \%)\end{array}$ & $\begin{array}{l}5 \\
(5.15 \%)\end{array}$ & $\begin{array}{l}0 \\
(0.00 \%)\end{array}$ \\
\hline Enhances positive attitude towards the school & $\begin{array}{l}83 \\
(85.57 \%)\end{array}$ & $\begin{array}{l}9 \\
(9.28 \%)\end{array}$ & $\begin{array}{l}2 \\
(2.06 \%)\end{array}$ & $\begin{array}{l}0 \\
(0.00 \%)\end{array}$ & $\begin{array}{l}3 \\
(3.09 \%)\end{array}$ \\
\hline $\begin{array}{l}\text { Makes the school environment physically and } \\
\text { psychologically secure for students }\end{array}$ & $\begin{array}{l}82 \\
(84.54 \%)\end{array}$ & $\begin{array}{l}10 \\
(10.31 \%)\end{array}$ & $\begin{array}{l}2 \\
(2.06 \%)\end{array}$ & $\begin{array}{l}2 \\
(2.06 \%)\end{array}$ & $\begin{array}{l}1 \\
(1.03 \%)\end{array}$ \\
\hline Improves students liking towards the school & $\begin{array}{l}80 \\
(82.47 \%)\end{array}$ & $\begin{array}{l}8 \\
(8.25 \%)\end{array}$ & $\begin{array}{l}5 \\
(5.15 \%)\end{array}$ & $(4.12 \%)$ & $\begin{array}{l}0 \\
(0.00 \%)\end{array}$ \\
\hline
\end{tabular}


Most of the school Principals/ Deputy school Principals strongly believed that guidance and counselling improves students' sense of belonging to their school and also enhances student teacher-relationship as shown by $90.72 \%$ and $87.3 \%$ of the respondents respectively. Majority of the respondents at $89.69 \%$ also strongly agreed with the statement that guidance and counselling programme boosts teachers respect towards students opinions, and also enhances students pride towards their school. (87.63). In fact, 86.0\% strongly agreed that guidance and counselling programmes in schools helps in improving teacher-student relationship. Only $4.12 \%$ disputed this statement. It was also found that guidance and counselling programmes help in promoting teachers and other adults concern towards students welfare and enhancing students participation in extra curricular activities in school as shown by $89.69 \%$ and $79.38 \%$ of the respondents respectively. The study also found that through guidance and counselling. Students developed a positive attitude towards the school and the school environment becomes physically and psychologically secure for students and this improves their liking towards the school as shown by $85.57 \%, 84.54 \%$ and $83.47 \%$ of the respondents respectively.

\subsection{Attitude and Perception of Teacher Counsellors Effect of Guidance and Counselling Programmes on Students Connectedness}

Guidance and counselling teachers were asked to indicate how guidance and counselling programme improved students school connectedness. The statements were measured using a 5-item 5-print likert scale as 1-strongly disagree (SD) 2=Disagree (D), 3= Neutral (N), $4=$ agree (A) and $\mathrm{S}=$ Strongly agree (SA). The data obtained was analyzed to show frequency of each response as well as percentage per item. The findings are shown in Table 2 below.

Table-2. Attitude and perception of Teacher Counsellors effect of guidance and counselling programmes on students connectedness students school connectedness

\begin{tabular}{|c|c|c|c|c|c|}
\hline Statement & $\mathbf{S A}$ & A & $\mathbf{N}$ & D & SD \\
\hline $\begin{array}{l}\text { Enhances teachers and other adults care towards } \\
\text { students }\end{array}$ & $\begin{array}{l}38 \\
(82.61 \%)\end{array}$ & $\begin{array}{l}5 \\
(10.87 \%)\end{array}$ & $\begin{array}{l}2 \\
(4.35 \%)\end{array}$ & $\begin{array}{l}0 \\
(0.00 \%)\end{array}$ & $\begin{array}{l}1 \\
(2.17 c\end{array}$ \\
\hline $\begin{array}{l}\text { Improves teachers and other adults treatment of } \\
\text { students }\end{array}$ & $\begin{array}{l}35 \\
(76.09 \%)\end{array}$ & $\begin{array}{l}9 \\
(19.57 \%)\end{array}$ & $\begin{array}{l}1 \\
(2.17 \%)\end{array}$ & $\begin{array}{l}1 \\
(2.17 \%)\end{array}$ & $\begin{array}{l}0 \\
(0.00 \%)\end{array}$ \\
\hline $\begin{array}{l}\text { Ensures that every student feels close to at least one } \\
\text { supportive adult at school }\end{array}$ & $\begin{array}{l}29 \\
(63.04 \%)\end{array}$ & $\begin{array}{l}13 \\
(28.26 \%)\end{array}$ & $\begin{array}{l}3 \\
(6.52 \%)\end{array}$ & $\begin{array}{l}1 \\
(2.17 \%)\end{array}$ & $\begin{array}{l}0 \\
(0.00 \%)\end{array}$ \\
\hline Encourages every student to reach his or her potential & $\begin{array}{l}41 \\
(89.13 \%)\end{array}$ & $(4.35 \%)$ & $\begin{array}{l}2 \\
(4.35 \%)\end{array}$ & $\begin{array}{l}0 \\
(0.00 \%)\end{array}$ & $\begin{array}{l}1 \\
(2.17 \%)\end{array}$ \\
\hline chers and other adults respect towards & $\begin{array}{l}34 \\
(73.91 \%)\end{array}$ & $\begin{array}{l}7 \\
(15.22 \%)\end{array}$ & $\begin{array}{l}3 \\
(6.52 \%)\end{array}$ & $\begin{array}{l}1 \\
(2.17 \%)\end{array}$ & $\begin{array}{l}1 \\
(2.17 \%)\end{array}$ \\
\hline $\begin{array}{l}\text { heet the diverse } \\
\text { of students }\end{array}$ & $\begin{array}{l}40 \\
(86.96 \%)\end{array}$ & $(4.35 \%)$ & $(4.35 \%)$ & $\begin{array}{l}1 \\
(2.17 \%)\end{array}$ & $\begin{array}{l}1 \\
(2.17 \%)\end{array}$ \\
\hline $\begin{array}{l}\text { port during times of academic } \\
\text { on }\end{array}$ & $(91.30 \%)$ & $(4.35 \%)$ & $\begin{array}{l}1 \\
(2.17 \%)\end{array}$ & $\begin{array}{l}1 \\
(2.17 \%)\end{array}$ & $(0.00 \%)$ \\
\hline $\begin{array}{l}\text { ciplinary policies that are } \\
\text { and fairly enforced }\end{array}$ & $(91.30 \%)$ & $(6.52 \%)$ & $(0.00 \%)$ & $(0.00 \%)$ & $\begin{array}{l}1 \\
(2.17 \%)\end{array}$ \\
\hline $\begin{array}{l}\text { Provides school and community based extra-curricular } \\
\text { activities }\end{array}$ & $\begin{array}{l}29 \\
(63.04 \%)\end{array}$ & $\begin{array}{l}13 \\
(28.26 \%)\end{array}$ & $(4.35 \%)$ & $\begin{array}{l}1 \\
(2.17 \%)\end{array}$ & $\begin{array}{l}1 \\
(2.17 \%)\end{array}$ \\
\hline $\begin{array}{l}\text { Provides students with emotional and social skills } \\
\text { necessary to be actively engaged in school }\end{array}$ & $\begin{array}{l}40 \\
(86.96 \%)\end{array}$ & $(4.35 \%)$ & $\begin{array}{l}3 \\
(6.52 \%)\end{array}$ & $\begin{array}{l}1 \\
(2.17 \%)\end{array}$ & $\begin{array}{l}0 \\
(0.00 \%)\end{array}$ \\
\hline
\end{tabular}

International Journal of Educational Studies

Vol. 2, No.3, pp. 151-162

DOI: $10.53935 / 2641-533 x . v 2 i 3.117$

Corresponding Author: Paul C. Ondima Funding: This study received no specific financial support.

Article History:

Received: 27 June 2019

Revised: 21 August 2019

Accepted: 2 October 2019

Published: 8 November 2019

(C) 2019 by the authors: licensee Academic

Publishing Group
Most of the guidance and counselling teachers at $82.1 \%$ strongly believed that guidance and counselling services enhance teachers and other adults care towards students and also improves teachers and other adults treatment of students as confirmed by $95.60 \%$ cumulatively. Over two thirds, $63.04 \%$, and $89.13 \%$ also strongly supported the statement that guidance and counselling services ensures that every student feels close to at least one supportive adult at school and encourages every student to reach his or her potential respectively. Majority of the respondents at $73.91 \%$ and $86.96 \%$ also strongly agreed with the statement that guidance and counselling services fosters teachers and other adults respect towards students and also supports teachers and other adults to meet the diverse cognitive, emotional and social needs of students respectively. It was also found that these services provide social support during times of academic change and transition as 
strongly indicated by $91.30 \%$. Another $91.30 \%$ also strongly agreed that guidance and counselling fosters application of disciplinary policies that are collectively agreed upon and fairly enforced. Infact $86.96 \%$ empleatically confirmed that guidance and counselling services provides students with emotional and social skills necessary to be actively in school activities.

\subsection{Students Opinion on Influence of Guidance and Counselling Programme on Students School Connectedness}

Students were also asked to indicate how guidance and counselling programme influenced their connectedness to the school. The statements were measured using a 5-item 5-point likert scale as $1=$ strongly disagree (SD), 2=Disagree (D), 3=(Neutral (n), 4= Agree (A) and 5= Strongly disagree (SA). The data obtained was analyzed to show frequency of each response as well as percentage per item and the results are presented in Table 3 below.

Table-3. Student opinion on influence of guidance and counselling programme on students school connectedness.

\begin{tabular}{|c|c|c|c|}
\hline Statement & Yes & 'an't tell & No \\
\hline $\begin{array}{l}\text { Do guidance and counselling improve your relationship } \\
\text { services }\end{array}$ & with $225(78.1$ & $16(5.5$ & $47(16.3$ \\
\hline teachers & $3 \%)$ & $6 \%)$ & $2 \%)$ \\
\hline $\begin{array}{l}\text { Whenever you break school rules, through guidance and counsellin } \\
\text { you }\end{array}$ & ng do 214(74.3 & $12(4.1$ & $62(21.5$ \\
\hline get an opportunity to explain yourself & $1 \%)$ & $7 \%)$ & $3 \%)$ \\
\hline $\begin{array}{l}\text { Does guidance and counselling contribute towards improving } \\
\text { treatment }\end{array}$ & the $226(78.4$ & $15(5.2$ & $47(16.3$ \\
\hline \multirow[t]{2}{*}{ you receive from teachers } & $7 \%)$ & $1 \%)$ & $2 \%)$ \\
\hline & $263(91.3$ & $15(5.2$ & $10(3.47$ \\
\hline \multicolumn{2}{|c|}{$\begin{array}{l}\text { Does guidance and counselling enhance your sense of belonging to the } 2 \% \text { ) } \\
\text { school }\end{array}$} & $1 \%)$ & $\%)$ \\
\hline & 274(95.1 & $11(3.8$ & $3(1.04$ \\
\hline Do you enjoy being in school as a result of guidance and counseling & $4 \%)$ & $2 \%)$ & $\%)$ \\
\hline $\begin{array}{l}\text { Do you enjoy participating in different school activities } \\
\text { receiving }\end{array}$ & after 199(69.1 & $14(4.8$ & $75(26.0$ \\
\hline guidance and counselling services & $0 \%)$ & $6 \%)$ & $4 \%)$ \\
\hline
\end{tabular}

Majority of the students revealed that guidance and counselling programs in schools have improved their sense of belonging to the school and also enhanced tier liking towards the school. This was strongly supported by $85.42 \%$ and $90.97 \%$ of the respondents respectively. Most of the students at $92.3 \%$ also strongly agreed that guidance and counselling programmes have improved their relationship with teachers and made them free to their teachers than before as shown by $91.67 \%$. It was also found that guidance and counsellng services had enhanced their pride towards their schools and had also increased their interest in extra-curricular activities as indicated by most of the students at $83.68 \%$ and $83.33 \%$.

Another $84.03 \%$ also strongly confirmed that guidance and counselling services had made the school environment physically and psychologically secure for them. Further, those services had made them feel loved and appreciated by members of school community as revealed by $85.07 \%$ of the respondents who strongly agreed with the statement. Similarly, in one of the interviews with the teacher counselors, one of them had this to say;

Guidance and counselling services for school going students is to improve academic achievement, foster positive altitude towards school, learning and work, increase acquisition and application of conflict resolution skills and finally decrease dropouts from schools (interview, Teacher counsellor 11, 14/5/2018)

These sentiments concur with that of who also found that the underachieving students who receive counselling improved significantly on their loving for the school and their relationship with the teachers.

Studies

Vol. 2, No.3, pp. 151-162

2019 Funding. This study received no specific financial support.

Received: 27 June 2019

Revised: 21 August 2019

Accepted: 2 October 2019

(C) 2019 by the authors; licensee Academic

Publishing Group 
4. Relationship between Guidance and Counselling Programme and students school connectedness

\subsection{Hypothesis Testing Null Hypothesis}

$\mathbf{H}_{0}$ : There is no statistically significant relationship between guidance and counselling programme and secondary students school connectedness.

To establish whether there was any significant relationship between guidance and counselling programmes and students' school connectedness, a Pearson correlation analysis was conducted between the two variables. Since data for guidance and counselling services and students school connectedness among form three students were measured on ordinal likert level for each item, it was important to obtain continuous data to facilitate performance of correlation analysis. This summated scores for each respondent were obtained for each of the two scores. The corresponding scores for each respondent were used as data points for the 288 student participants.

The null hypothesis was to be tested at 0.05 significance/alpha level $(\propto)$. The test statistic is converted to aconditional probability called a $\mathrm{q}$ value. If $\mathrm{q} \leq \propto$ the null hypothesis is rejected, meaning that the observed difference is significant, that is, not due to chance. However if the $-\mathrm{q}$ value will be greater than 0.05 (i.e $\mathrm{q}>\propto$ ) the null hypothesis will not be rejected, meaning that the observed difference between the variables is not significant. The correlation output is presented in Table 4 below:

Table-4. Correlation output for guidance and counselling programmes and students school connectedness.

\begin{tabular}{llll}
\hline & & $\begin{array}{l}\text { Guidance and counseling } \\
\text { Services }\end{array}$ & $\begin{array}{l}\text { Students } \\
\text { Connectedness }\end{array}$ \\
\hline $\begin{array}{l}\text { Guidance and } \\
\text { counseling services }\end{array}$ & Pearson Correlation & 1 & $0.622^{* * *}$ \\
& Sig. (2-tailed) & & 0.000 \\
Students & $\mathrm{N}$ & 288 & 288 \\
Connectedness & Pearson Correlation & $0.622^{* *}$ & 1 \\
& & & \\
& Sig. (2-tailed) & 0.000 & 288 \\
\hline Note: **. Correlation is significant at the 0.05 level (2-tailed). & 288 &
\end{tabular}

The findings in Table 4 show that there is a strong positive relationship $(R=.622)$ between guidance and counselling programmes and students school connectedness which was statically significant $(\mathrm{q}<.005)$. Since the significance (q-value) of leveve's test $(0.003)$ is less than $\propto$ level $(0.05)$ then the null hypothesis is rejected that is the variances of the two groups are equal, implying that the variances are not equal. The findings show that q- value is less than the significance level $(0.05)$. That is $0.00<0.05$. This implies that more guidance and counselling services in schools significantly increases students school connectedness.

\subsection{Regression Analysis of Guidance and Counselling Programmes and Students School Connectedness}

To determine the effects of guidance and counselling programmes on students school connectedness, regression analysis was conducted between the variables. Data collected was converted to continuous data by summating the individual item scores in the scale for each respondent. The output is presented in Table 5 below.

International Journal of Educational Studies

Vol. 2, No.3, pp. 151-162

2019

DOI: $10.53935 / 2641-533 x . v 2 i 3.117$

"Corresponding Author: Paul C. Ondima Funding: This study received no specific financial support.

Article History:

Received: 27 June 2019

Revised: 21 August 2019

Accepted: 2 October 2019

Published: 8 November 2019

(C) 2019 by the authors: licensee Academic

Publishing Group
Table-5. Regression output for guidance and counselling programmes and students school connectedness.

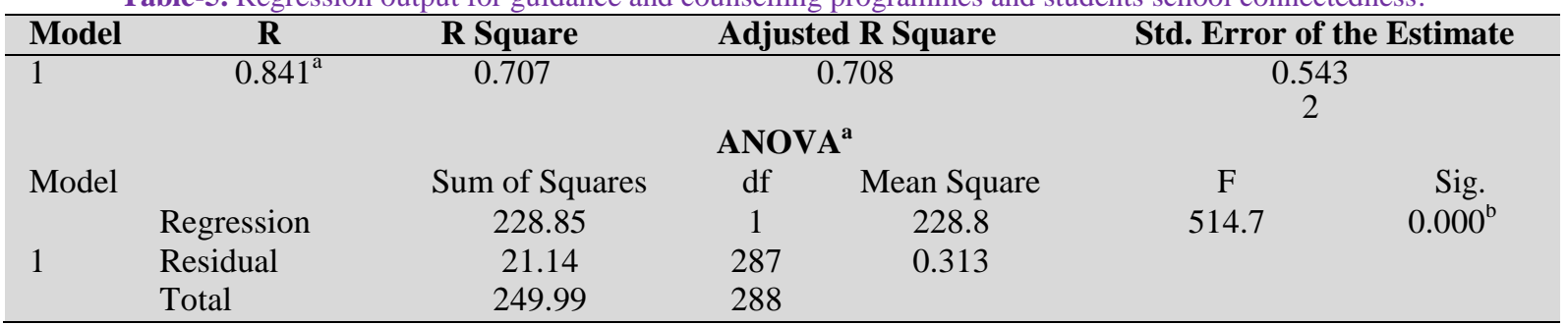




\begin{tabular}{llllllll}
\hline & & \multicolumn{2}{l}{$\begin{array}{l}\text { Unstandardized } \\
\text { Coefficients }\end{array}$} & & \multicolumn{3}{c}{$\begin{array}{l}\text { Standardized } \\
\text { Coefficients }\end{array}$} \\
\cline { 2 - 8 } Model & & B & Std. Error & Beta & & \\
& & (Constant) & 56.40 & 0.444 & & 51.86 & 0.000 \\
1 & Guidance and Counseling services & 0.781 & 0.018 & 0.871 & 22.73 & 0.000 \\
\hline
\end{tabular}

The study found that guidance and counselling services explained upto $70.7 \%$ ( $\mathrm{R}$ square $=.707$ of variance in the students school connectedness. The model was found to be statistically significant as $\mathrm{F}(1,288)$ $=514.7)(\mathrm{q}<.05)$. Thus from regression, guidance and counselling programmes are able to account for $70.7 \%$ of variance in the students school connectedness. The variables were modeled to be connected by the linear regression equation in the form:

$\mathrm{Y}=\mathrm{B}_{0}+\mathrm{B} 1 \mathrm{X} 1+\epsilon$

Where $\mathrm{Y}$ is students connectedness, $\mathrm{B}_{0}$ is coefficient of constant term, $\mathrm{B}_{1}$ is coefficient of guidance and counselling programmes, $X_{1}$ is guidance and counselling programmes and is error term. Thus, replacing the coefficients of regression the equation becomes;

$\mathrm{Y}=56.40+0.781 \mathrm{X}^{1}$

This shows that when guidance and counselling services change by one positive unit, students school connectedness increases by 0.781 . Thus guidance and counselling services positively affects students school connectedness to a magnitude of 0.781 as indicated by the main effects.

\section{Discussion}

The purpose of this study was to find out the effect of guidance and counselling programmes on students school connectedness. All the respondents at $100 \%$ agreed that they had guidance and counselling department in their schools that may help the students in solving various academic and social challenges. When probed on the main services offered by the department, over two thirds indicated counselling services, $26.09 \%$ mentioned consultancy services while $52 \%$ and $4.35 \%$ indicated referral and outreach respectively. On modes of counselling used in the provision of guidance and counselling services, almost all the respondents at $97.83 \%$ indicated one-on-one counselling, 23.91\% indicated group counselling, while $45.5 \%$ mentioned peer counselling. This shows that the main modes of administration of guidance and counselling services were one-on-one and peer counselling. The study revealed that most of the students would offer themselves for counselling voluntarily as shown by $60.87 \%$ of the teacher counsellors who participated in the study. Only $26.09 \%$ indicated otherwise. Majority of the respondents at $89.13 \%$ believed in their view that guidance and counsellling enhanced students pride in their school while $6.52 \%$ disputed the statement as $4.35 \%$ could not tell. Another $84.78 \%$ confirmed that guidance and counselling services in the schools provided students with emotional and social skills necessary to be actively engaged in school. Only $4.35 \%$ believed otherwise. Majority of the respondents at $86.96 \%$ also believed that guidance and counselling promote students sense of belonging to the school and also create a trusting and caring relationship between students, teachers and adult members in the schools as shown by $89.13 \%$.Correlation analysis reveals that there is a strong positive relationship ( $\mathrm{r}=.622)$ between guidance and counselling services and students school connectedness which was statistically significant $(q<.005)$. This implies that it can be statistically shown that more guidance and counselling services in schools significantly increases students school connectedness. Using linear regression analysis the coefficient of regression on the equation becomes; $\mathrm{Y}=56.40+0.781 \mathrm{X}_{1}$, showing that, when guidance and counselling services change by one positive unit, students connectedness increases by 0.781 . Thus guidance and counseling services positively affects students school connectedness to a magnitude of 0.781 as indicated by the main effects. Therefore the null hypothesis $\mathrm{H}_{0}$ of; there is no significant relationship between guidance and counselling services and secondary school students connectedness was rejected.

\section{Conclusions}

Based on the findings of this study which have been discussed in the foregoing sections, the following conclusions have been drawn.

- The guidance and counseling programmes have contributed towards making students feel loved and appreciated by members of the school community.

- The school environment has been made physically and psychologically secure for students through the

International Journal of Educational
Studies
Vol. 2, No.3, pp. 151-162
2019
DOI: $10.53935 / 2641-533 x . v 2 i 3.117$
Corresponding Author: Paul C. Ondima
Funding: This study received no specific
financial support.
Article History:
Received: 27 June 2019
Revised: 21 August 2019
Accepted: 2 October 2019
Published: 8 November 2019
@ 2019 by the authors; licensee Academic
Publishing Group
$\quad$ | 161
| 161 
guidance and counselling programmes which in turn has fostered their positive attitude towards the school.

- The guidance and counselling programmes enhances teachers and other adult members of school community's respect towards students and supports the former to meet the diverse, cognitive, emotional and social needs of students.

- Guidance and counselling programmes in secondary schools have boosted their liking towards the school, improved their pride towards the school and increased their interest in extra-curricular activities.

- Guidance and counselling programs fosters a positive teacher student relationship which goes a long way in enhancing student school connectedness. A high students sense of school connectedness helps to create a healthy emotional and cognitive development of secondary school students which is one of the strongest protective factors of high-risk behaviours such as substance abuse, violence and suicidal tendencies.

\section{Recommendations}

In view of the fact that guidance and counselling programmes play a critical role in enhancing secondary school students school connectedness as evidenced in the study findings, the following recommendations are made for policy and practice:

- The government through the Ministry of Education and the Teachers Service Commission should deploy more teacher counselors in schools to effectively tackle the social and academic challenges facing students.

- The guidance and counselling programmes in the schools should be strengthened through equipping the G/C department and providing more moral and financial support to the department.

- The Ministry of education and other stakeholders should organize regular seminars and workshops to offer continuing education on guidance and counselling. This will equip the teacher counsellors with latest theories and techniques of counselling to make them more effective in the provision of guidance and counselling services.

\section{Suggestions for Future Research}

The researchers recommend future research in the following aspects of guidance and counseling.

- Impact of teacher-student relationship on students school connectedness.

- Influence of secondary students school connectedness on academic performance.

- Modes of delivery of guidance and counselling services and their influence on students school connectedness.

- Role of parents in enhancing student school connectedness.

\section{References}

Carey, J., Harrington, K., Martin, I., \& Hoffman, D. (2012). A statewide evaluation of the outcomes of the implementation of ASCA National Model school counseling programs in rural and suburban Nebraska high schools. Professional School Counseling, 16(2), 2156759X0001600202.

Frankel, J. R., \& Wallen, E. N. (2014). How to design and evaluate research in education. San Francisco: San Francisco University.

Gauta, D. M. (2012). Impact of guidance and counselling services on students social and emotional adjustment in public urban and rural secondary schools in Nakuru and Uasin Gishu Counties, Kenya. International Journal of Science and Research, 3(11), 431-438.

Lunenburg, F. C. (2010). Communication: The process, barriers, and improving effectiveness. Schooling, 1(1), 1-10.

Machingambi, S. (2012). How do schools push students out of school? A case study of two rural secondary schools in Masvingo district of Zimbabwe. Journal of Social Sciences, 30(1), 55-63.

Mohan, H. (2010). Textbook of pathology. New Delhi: Jaypee Brothers Medical Publishers.

Okolie, U. C., \& Nweze, T. (2014). Effective guidance and couneslling programmes in secondary schools: Issues and roles in students career. Decision Making: Journal of Research and Methods in Education, 4(4), 63-68.

Onderi, J., \& Makori. (2013). Essentials of educational and social science research methods. Nairobi: Mazola Publishers.

Ross, A. G., Shochet, I. M., \& Bellair, R. (2010). The role of social skills and school connectedness in preadolescent depressive symptoms. Journal of Clinical Child \& Adolescent Psychology, 39(2), 269-275.

Shochet, I. M., \& Smith, C. L. (2011). A prospective study investigating the links among classroom environment, school connectedness, and depressive symptoms in adolescents. Psychology in the Schools, 51(5), 480-492.

Whiston, S. C., Tai, W. L., Rahardja, D., \& Eder, K. (2011). School counseling outcome: A meta-analytic examination of interventions. Journal of Counseling \& Development, 89(1), 37-55. 